\title{
FAKTOR-FAKTOR PENYEBAB PENYIMPANGAN DALAM TAFSIR
}

\author{
Ozi Setiadi, MA. \\ Mahasiswa Pascasarjana UIN Syarif Hidayatullah Jakarta \\ ozisetiadi@gmail.com
}

\begin{abstract}
Abstrak
Tafsir merupakan cara untuk memahami Al-Qur'an. Keberadaannya menjadi sebuah keharusan karena ayat-ayat yang terdapat dalam Al-Qur'an bersifat umum, sehingga tidak mudah untuk dipahami. Akan tetapi, meski tafsir menjadi satu-satunya jalan untuk memahami Al-Qur'an, bukan berarti bahwa ia terbebas dari penyimpangan. Penyimpangan ini dapat berakibat semakin jauh seseorang dari pemahaman terhadap makna Al-Qur'an yang sesungguhnya. Oleh karenanya, berbagai faktor penyebab penyimpangan dalam tafsir perlu dideteksi dan kemudian dieliminir agar penyimpangan terhadap penafsiran Al-Qur'an dapat dihindari. Beberapa faktor penyebab penyimpangan dalam tafsir adalah subjektifitas mufassir, kekeliruan dalam menetapkan metode atau kaidah, kedangkalan dalam ilmu-ilmu alat, kedangkalan pengetahuan tentang materi uraian (pembicaraan) ayat, tidak memperhatikan konteks, dan tidak memperhatikan siapa pembicara dan terhadap siapa pembicara itu ditujukan. Selain itu kesamaran karena jarak antara nabi dengan umat yang cukup jauh, faktor materi, dan faktor histori turut serta mendukung penyimpangan dalam tafsir.
\end{abstract}

Tafseer is a way of understanding the Qur'an. Its existence becomes a necessity because the verses contained in the Qur'an are general, so it is not easy to understand. However, while interpretation is the only way to understand the Qur'an, it does not mean that it is free from perversion. This deviation can result in an increasingly distant person from understanding the true meaning of the Quran. Therefore, various factors causing deviations in the interpretation need to be detected and then eliminated so that deviations from the interpretation of the Quran can be avoided. Some of the factors causing irregularities in the commentary are the subjectivity of the exegete, the error in setting the method or rule, superficiality in the sciences, the superficial knowledge of the subject matter (speech) verse, regardless of the context, and not paying attention to who the speaker is and to whom the speaker is addressed. Besides the disguise because the distance between the prophet and the people who are far enough, the material factors, and the factors of history to participate in supporting the irregularities in the tafseer.

Keywords: Irregularities, Tafseer, Quran 


\section{A. Pendahuluan}

Al-Qur'an adalah kitab suci bagi umat Islam di seluruh dunia. Kitab suci yang diturunkan oleh Allah S.W.T. kepada Nabi Muhammad S.A.W. melalui malaikat Jibril dengan menggunakan Bahasa Arab. ${ }^{1}$ Berisi tidak hanya data-data terkait fakta sejarah dan ilmu pengetahuan, tetapi juga aturan hukum (syariat) bagi umat Islam. ${ }^{2}$ Fungsi utama Al-Qur'an sebagai pedoman hidup, mengandung aspekaspek yang universal (mujmal). ${ }^{3}$ Artinya, tidak semua aspek dalam AlQur'an bisa dipahami dengan mudah oleh umat Islam. Terdapat ayat-ayat yang sulit untuk dipahami dan memerlukan penafsiran. Al-Qur'an

1 Sama halnya dengan Imam Muchlas yang berpendapat bahwa Al-Qur'an adalah kitab suci yang berisi kata-kata atau kalimat dalam bahasa Arab, yang diturunkan kepada Nabi Muhammad S.A.W. yang diriwayatkan dan tersebar secara mutawatir. Segala kata-katanya hingga huruf yang terdapat pada tulisan AlQur'an adalah sama pada saat ditulis pertama kalinya, dan dinilai ibadah bagi siapa yang membacanya. Imam Muchlas. 1995. Al-Qur'an Berbicara: Kajian Kontekstual Beragam Persoalan. Sidoarjo: Pustaka Progresif. hlm. 19.

2 Al-Qur'an, kitab cahaya, yang pancarannya melahirkan berabagai macam ilmu keislaman, karena Al-Qur'an mendorong seseorang guna melakukan pengamatan dan penelitian. M. Quraisy Shihab. 2013. Kaidah Tafsir, Syarat, Ketentuan, dan Aturan yang Patut Anda Ketahui dalam Memahami AyatAyat Al-Qur'an. Tangerang Selatan: Lentera Hati. hlm. 5.

${ }^{3}$ QS. Al-Baqarah: 2

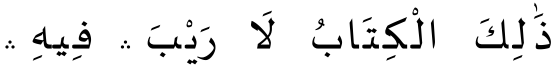



sendiri mendorong untuk dilakukan pengamatan dan penelitian atasnya. ${ }^{4}$

Penafsiran terhadap Al-Qur'an adalah sebuah langkah yang kemudian memunculkan berbagai disiplin ilmu, utamanya ilmu tafsir, sebagai wujud pengamatan dan penelitian. Ilmu ini membahas tentang Al-Qur'an yang mulia dari segi penunjukannya terhadap maksud Allah S.W.T. sesuai kemampuan manusia. ${ }^{5}$ Penafsiran AlQur'an dilakukan dengan menggunakan banyak metode. ${ }^{6}$ Metode bil ma'tsur, bir ra'yi dan bi isyari adalah metode yang umum digunakan oleh para mufassir untuk menafsirkan Al-Qur'an. Hal ini disebabkan hanya melalui penafsiran Al-Qur'an dapat dengan mudah dipahami. Meskipun demikian, bukan berarti penafsiran terhadap AlQur'an dengan menggunakan metodemetode tersebut dapat membebaskan mufassir dari kesalahan, sebaliknya penyimpangan-penyimpangan terhadap penafsiran Al-Qur'an masih bisa saja terjadi.

4 M. Quraish Shihab. Kaidah Tafsir Syarat, Ketentuan, dan Aturan yang Patut Anda Ketahui dalam Memahami Ayat-ayat Al-Qur'an. hlm. 5.

${ }^{55}$ Ahmad Thib Raya, "Kaidah Tafsir Terkait dengan Metode Tafsir: Terjemahan dari Buku. 2013. Qawa'id al-Tafsir Jam'an wa Dirasat Oleh Khalid al-Sabt. Tangerang Selatan: Yayasan Lentera Hati. hlm. 1.

Metode mengandung makna seperangkat kaidah dan aturan-aturan yang wajib diperhatikan oleh para mufassir agar terhindar dari kesalahan-kesalahan dan penyimpangan-penyimpangan dalam menafsirkan ayat Al-Qur'an. Supiana dan M. Karman. 2012. 'Ulumul Qur'an dan Pengenalan Metodologi Tafsir. Bandung: Pustaka Islamika. hlm. 302. 
Berbagai penyimpangan terhadap penafsiran Al-Qur'an bisa terjadi seiring dengan keinginan para mufassir dalam menafsirkan Al-Qur'an. Selain faktor internal tersebut, faktor eksternal juga turut ambil bagian dalam terjadinya penyimpangan dalam penafsiran AlQur'an. Penyimpangan sejarah yang terjadi sejak awal, pemikiran-pemikiran terdahulu yang dapat mewarnai pemikiran para mufassir berikutnya, dan politik serta sosio kultural turut ambil bagian yang memungkinkan tejadi penyimpangan tersebut. Akibatnya, para pembaca yang ingin membaca tafsir ayat-ayat Al-Qur'an harus lebih teliti dan berhati-hati dalam melihat tafsir tersebut.

Adanya berbagai faktor yang mendorong terjadinya penyimpangan dalam penafsiran Al-Qur'an membuat penulis menganggap penting untuk dilakukan kajian secara khusus terkait dengan faktor-faktor penyimpangan dalam tafsir. Ini diperlukan guna mengetahui faktor apa saja yang dapat menyebabkan terjadinya penyimpangan dalam tafsir. Selain juga untuk mengkaji lebih dalam tentang benarkah berbagai faktor yang disebutkan telah menyebabkan kesalahan dalam penafsiran, serta bagaimana dampaknya? Tulisan ini akan menjelaskan hal-hal demikian.

\section{B. Makna dan Jenis Tafsir}

Al-Qur'an adalah kitab suci yang paripurna, mencakup semua aspek kehidupan. Keluasan kandungan AlQur'an membuatnya harus ditafsirkan sesuai dengan perkembangan zaman. Tak pernah terputus, penafsiran AlQur'an harus senantiasa dilakukan secara terus-menerus, sesuai dengan kebutuhan zamannya. Oleh sebab itu, penafsiran Al-Qur'an adalah sebuah keniscayaan, ${ }^{7}$ tidak hanya melibatkan ilmu bahasa Arab, tetapi juga berbagai disiplin ilmu yang lain, sehingga saling menguatkan. ${ }^{8}$

Tafsir memiliki makna yang variatif, bergantung pada siapa yang mendefenisikannya. Akan tetapi, secara etimologi tafsir merupakan bentuk ta'fil dari kata fassara, yang bermakna menerangkan, membuka, dan menjelaskan (al-bayan). Al-Fasru dalam bahasa Arab berarti membuka arti yang sukar, sedang kata at-tafsir berarti membuka atau menjelaskan arti yang dimaksudkan dari lafad-lafad yang

${ }^{7}$ Arifin. 2008. Sejarah Tafsir Klasik dan Kontemporer. Surakarta: STAIN Surakarta. hlm. 1.

8 Terdapat perbedaan di antara cendekiawan Muslim terkait dengan Bahasa Arab sebagai bahasa Al-Qur'an. Setidaknya terdapat tiga kelompok yang memiliki pendapat masing-masing terkait bahasa yang ada pada AlQur'an. Kelompok pertama adalah para ulama yang berpendapat bahwa Al-Qur'an mengandung sebagian Bahasa non-Arab ('ajam). Kelompok kedua adalah yang lain berpendapat bahwa dalam Al-Qur'an tidak ada bahasa lain selain Bahasa Arab. Kalaupun ada bahasa non Arab, maka itu hanya berkaitan dengan nama saja. Sedang yang ketiga adalah kelompok yang moderat yang menengahi perbedaan atas dua kelompok sebelumnya, yakni yang berpendapat bahwa memang di dalam Al-Qur'an terdapat bahasa non-Arab, tetapi bila bahasa tersebut sudah terpakai di kalangan Arab, maka menjadi bahasa Arab sekalipun awalnya dari bahasa non Arab. Lihat dalam Muhammad Al-Zafzaf. al-Ta'rif bi AlQur'an wa Al-Hadith. Kairo: Kulliyat Dar alUlum Jami' al-Qohirah, t.t. hlm. 8. 
sulit. ${ }^{9}$ Setidaknya yang dikemukakan oleh Al-Qhaththan ini dapat memberikan gambaran tentang makna tafsir.

Sedangkan secara terminologi, tafsir dapat dirumuskan melalui pendapat para cendekiawan yang di dalam penjelasannya terdapat kesepahaman dalam mendefenisikan tafsir, seperti Jalaluddin As-Suyuti, Imam Abu Hayyan, Hasbie AsShiddiqie, dan Az-Zarkasyi. Mereka menjelaskan bahwa tafsir adalah ilmu tentang Al-Qur'an yang di dalamnya terdapat sebab turun Al-Qur'an, letak turun ayat Al-Qur'an (makkiyah dan madaniyah), lafadz, hukum, redaksional, makna, dan hal terkait AlQur'an lainnya. ${ }^{10}$ Selain pendapat yang

9 Manna' Khalil Al-Qhaththan. 1992. Munahis fi Ulum Al-Qur'an. Riyadh: Al Maktabah Al Ma'arif li An Nasyri wa AtTanzil. hlm. 227. Faath menjelaskan bahwa tafsir berasal dari kata $J-\omega-\dot{\omega}($ fa-sa-ra) atau فسر (fasara) yang memiliki makna بين (bayana) yakni menjelaskan dan وضح (wadaha) yang berarti menerangkan. Amir Faisol Faath, Pemikiran Moderat dalam Tafsir Al-Qur'an, 42-70 . lihat juga Ahmad Satori Ismail. 2012. Islam Moderat: Menebar Islam Rahmatan Lil 'Alamin. Jakarta: Pustaka IKADI. hlm. 1-6.

${ }^{10}$ (a) Jalaluddin As-Suyuti menjelaskan tafsir adalah mengenai turunnya ayat-ayat dan ihwalnya, cerita-cerita dan sebab-sebab turunnya, makkiyah dan madaniyah, muhkam dan muhtasyabihat, nasikh dan mansukhnya, khusus dan umumnya, mutlaq dan muqayyadnya, mujmal dan mufassar-nya, halal dan haramnya, janji dan ancamannya, perintah dan larangannya, dan mengenai ungkapan dan perumpamaan-perumpamaannya. (b) Imam Abu Hayyan merumuskan bahwa tafsir adalah ilmu yang membahas tentang cara-cara mengucapkan lafal-lafal Al-Qur'an dan menerangkan petunjuk-petunjuk serta hukum-hukumya, baik yang mufrad (kata) maupun murakkab (kalimat) dan menjelaskan makna yang dibawa oleh lafallafal itu ketika dalam susunan dan redaksi, serta ulasan-ulasan yang melengkapi semua itu. dikemukakan oleh para cendekiawan Muslim tersebut, ada pula pendapat yang mendefinisikan tafsir sebagai ilmu yang mempelajari kandungan kitab Allah S.W.T. yang diturunkan kepada Nabi Muhammad S.A.W., berikut penjelasan makna serta hikmahhikmahnya. $^{11}$ Bahkan tafsir juga didefinisikan sebagai penjelasan atas maksud yang sukar dari suatu hal. ${ }^{12}$ Berdasarkan penjelasan ini, maka secara sederhana dapat disimpulkan bahwa tafsir adalah sebuah disiplin ilmu yang berkaitan langsung dengan pemahaman terhadap kandungan Al-Qur'an.

Sedangkan dari jenisnya, secara umum tafsir dapat dibedakan menjadi tiga, yakni tafsir bi al-ma'tsur, tafsir bi ar-ra'yi, dan tafsir bil-isyari. AlQhaththan menambahkannya dengan tafsir sufi. ${ }^{13}$ Tafsir bi al-ma'tsur (alma'tsur) secara etimologi berasal dari kata atsar yang berarti bekas, yakni segala sesuatu yang ditinggalkan oleh generasi sebelumnya. ${ }^{14}$ Sedangkan

Muhammad Husain Adz-Dzahabi. 1976. At Tafsir wa Al-Mufassirun. Kairo: Sar Al-Kutub Al-Arabi. Jilid II, hlm. 174. (c) Hasbi asShiddiqiey berpendapat bahwa tafsir adalah mensyaratkan lafadz yang sukar dipahami oleh pendengar dengan menjelaskan maksudnya. Yang demikian itu, ada kalanya dengan menyebut sinonimnya, atau yang menekatinya. Hasbi Ash Shiddiqiey. 1999. Sejarah dan Pengantar Ilmu Hadis. Semarang: Pustaka Rizki Putra. Cet. V, hlm. 122.

${ }_{11}$ Charles Diehl dan Georges Macais. 1936. Le Monde Orientalde. Paris: Histoire Generale. hlm. 123.

12 Ibnu Manzhur. Lisan Al Arab. Beirut: Daar Shadir, t.t. hlm. 55.

13 Baca Manna Khalil Al-Qhaththan. Studi Ilmu-ilmu Al-Qur'an. Bogor: Litera Antar Nusa, t.t. cet. II, hlm. 482-495.

14 Muhammad Husein Adz-Dzahabi. 1976. at-Tafsir wa al-Mufassirun. Kairo: Sar Al-Kutub Al-Arabi. cet. II, hlm. 174. 
menurut istilah tafsir bi al-ma'tsur adalah tafsir yang merujuk kepada riwayat atau tafsir yang menjadikan riwayat sebagai sumber utamanya. ${ }^{15}$ Seperti yang diriwayatkan dari Rasulullah S.A.W., dari sahabatsahabat, dari tabi'in, yang kesemuanya sebagai keterangan dan penjelasan bagi maksud Allah dari nash-nash kitab AlQur'an. ${ }^{16}$ Secara mujmal para ulama mengemukakan bahwa tafsir al-ma'tsur menempati tingkatan tertinggi dalam posisi, sebab penafsiran ayat Al-Qur'an dilakukan oleh Al-Qur'an itu sendiri, jauh dari intervensi subjektif. ${ }^{17}$

Berbeda dengan tafsir bi alMa'tsur, tafsir bi ar-ra'yi adalah penafsiran Al-Qur'an yang menjadikan hasil penalaran sebagai sumber utamanya. Penafsiran dengan model seperti ini kemudian juga dikenal dengan sebutan tafsir al-ijtihadi. Hal ini disebabkan tafsir tersebut lebih mengedepankan kemampuan rasional

15 Hasbi Ash Shiddiqy. Sejarah dan Pengantar Ilmu Hadis. hlm. 22.

${ }^{16}$ Said Agil Husin Al Munawar. 2005. Al-Qur'an Membangun Tradisi Kesalehan Hakiki. Tagerang Selatan: Ciputat. hlm. 77.

17 M. Quraisy Shihab. Kaidah Tafsir, Syarat, Ketentuan, dan Aturan yang Patut Anda Ketahui dalam Memahami Ayat-Ayat AlQur'an. hlm. 350. Adz Dzahabi menjelaskan bahwa at tafsir bi al ma'tsur adalah penjelasan terhadap ayat-ayat Al-Qur'an dengan mempergunakan : a) ayat-ayat Al-Qur'an, b) riwayat yang berasal dari Rasulullah, c) riwayat dari sahabat, atau d) riwayat dari para tabi'in. Sedangkan Az-Zarqani memiliki pendapat yang berbeda, yakni tidak memasukkan tabi'in dalam tafsir bi al ma'tsur. Hal ini karena ia menganggap para tabi'in termasuk di dalam cakupan al-atlas, sementara kata al-atlas terbatas pada hadis dan qaul para sahabat. Oleh karenanya, ungkapan para tabi' in dalam hal ini termasuk dalam kelompok ar-ra'yu. Pendapat Az-Zarqani tersebut bermula dari kata al atsar. untuk menjelaskan makna ayat-ayat AlQur'an. ${ }^{18}$ Tafsir ini hadir sebagai akibat logis dari perintah Al-Qur'an yang di dalam berbagai ayat acapkali diakhiri dengan afalạ ta'kilun, afala tattafakkarun, dan seterusnya yang menuntut manusia untuk menggunakan akal pikirannya.

\section{Sedangkan tafsir bil-isyari} memiliki makna yang mirip dengan namanya, yakni isyarah dalam Bahasa Arab yang berarti isyarat dalam Bahasa Indonesia. ${ }^{19}$ Akan tetapi, secara etimologi, isyari terdiri dari tiga suku kata, syin, waw, dan ra yang dibaca syawara. Kata inilah kemudian yang mendasari kata isyari yang berarti memetik. Oleh beberapa ulama, tafsir bil-isyari diterjemahkan secara beragam, namun memiliki maksud dan tujuan yang sama.

M. Quraisy Shihab menjelaskan bahwa tafsir bil-isyari merupakan upaya penarikan makna ayat Al-Qur'an berdasarkan kesan yang ditimbulkan dari lafadz ayat di dalam benak para mufassir yang sudah memiliki pencerahan batin atau hati dan pikiran, tanpa mengabaikan atau membatalkan

18 Azyumardi Azra (ed). Sejarah dan Ulum al-Quran. Jakarta: Pustaka Firdaus, t.t), hlm. 176. Tafsir bi ar ra'yi berasal dari kata berasal dari kata ar ra'yu yang berarti pikiran atau nalar.

19 Muhammad Husein Adz Dzahabi mendefenisikan isyarah sebagai sebuah usaha untuk menjelaskan kandungan Al-Qur'an dengan melakukan pentakwilan ayat-ayat sesuai dengan isyarat yang tersirat, namun tidak mengingkari yang tersurat atau dimensi zahir ayat. Muhammad Husain adz Dzahabi. al Tafsir wa al Mufassirun. hlm. 352. 
makna dari sisi lafadz. ${ }^{20}$ Pencerahan batin dan pikiran menjadi fokus dalam jenis tafsir ini. Oleh karenanya, tafsir jenis ini dikenal sebagai tafsir yang bercorak tasawuf karena para mufasir secara konsisten melakukan pengendalian atas hawa nafsu guna menjaga kebersihan dan ketulusan batiniahnya. $^{21}$

\section{Kritik terhadap Tafsir bi al Ma'tsur}

Penafsiran Al-Qur'an dengan menggunakan mentode bi al-ma'tsur bukan berarti tanpa kritik. Para ulama sependapat bahwa tafsir ini menggunakan cara penafsiran AlQur'an berdasarkan nash-nash, baik dengan Al-Qur'an itu sendiri, dengan aqwal sahabat, maupun dengan aqwal tabiin. Penafsiran ayat dengan pendapat Rasulullah Saw. memiliki validitas yang sangat tinggi, karena yang paling mengetahui maksud suatu ayat adalah Allah S.W.T. dan Rasulullah S.A.W. ${ }^{22}$ Rasul S.A.W. menjadi satu-satunya manusia yang paling memahami AlQur'an, sebab hati dan pikiran beliau langsung dibimbing oleh Allah S.W.T.

${ }^{20}$ M. Quraisy Shihab. Kaidah Tafsir, Syarat, Ketentuan, dan Aturan yang Patut Anda Ketahui dalam Memahami Ayat-Ayat AlQur'an. hlm. 373.

${ }^{21}$ Tafsir isyari dikenal juga sebagai representasi dari tafsir ortodoks atau sunni 'amali. Baca lebih lanjut dalam Aik Iksan Anshori. 2012. Tafsir Ishari Pendekatan Hermeneutika Sufistik Tafsir Shaikh 'Abd alQadir al Jilani Jakarta: Referensi, hlm. 33.

22 Tatkala Rasulullah S.A.W. masih hidup, tidak ada seorang sahabat pun yang berani menggantikan tugas Rasulullah S.A.W. dalam menafsirkan Al-Qur'an sampai akhir hayat beliau.
Oleh sebab itu, akhlak rasul S.A.W. digambarkan sebagai Al-Qur'an. Sebagaimana hadis yang diriwayatkan oleh imam Ahmad:

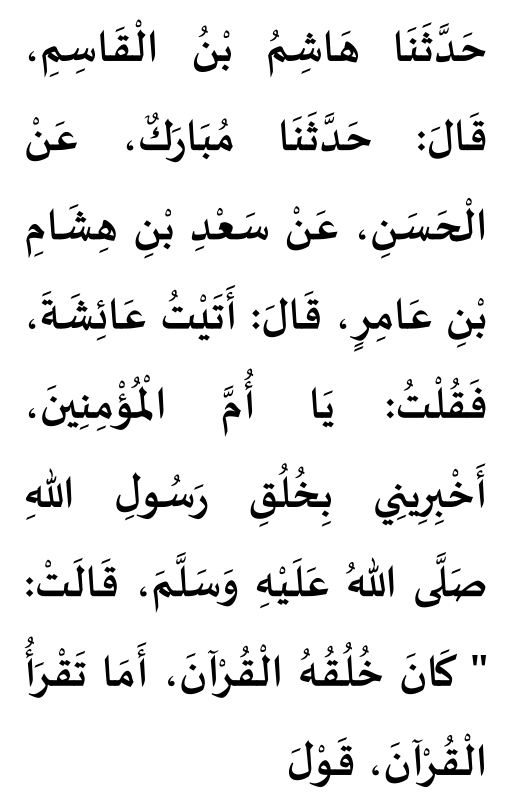

Telah meriwayatkan

Hasyim Ibnu Qasim,

berkata: telah

meriwayatkan Mubarak, dari Hasan, dari Sa'id Ibnu Hisyam Ibnu 'Amir, berkata: Aku menemui A'isyah, lalu aku berkata: "Wahai ummul mu'minin, kabarkanlah kepadaku tentang akhlak Rasulullah Saw." Maka ia menjawab, "Akhlak Rasulullah S.A.W. seperti Al-Quran”. (HR. Ahmad)

Meski Rasul S.A.W. berakhlak seperti Al-Qur'an, tetapi beliau bukanlah teks Al-Qur'an itu sendiri. Karena Al-Qur'an adalah kitab yang diyakini oleh seluruh umat Muslim di dunia, dan ia terpisah dari Rasulullah S.A.W. Ini berarti bahwa Rasul S.A.W. 
berfungsi sebagai mubayyin (pemberi penjelasan) terhadap maksud ayat-ayat Al-Quran, ${ }^{23}$ yang diturunkan oleh Allah kepada beliau. Oleh karenanya, tafsir ayat-ayat Al-Qur'an yang ditafsirkan oleh rasul S.A.W. memiliki keududukan yang kuat dan tinggi. Berbeda dengan tafsir yang disandarkan kepada para sahabat dan tabi'in yang banyak memiliki kelemahan. ${ }^{24}$ Abu Hanifah bahkan pernah berkata, "Apa saja yang berasal dari Rasulullah S.A.W., maka kita junjung tinggi, dan apa yang datang dari para sahabat kita pilih, sedangkan apa yang datang dari tabi'in, maka mereka laki-laki dan kita juga lakilaki". 25

Quraisy Shihab mengemukakan bahwa pada beberapa pendekatan tafsir tetap memiliki kekurangan, seperti pada tafsri bi al ma'tsur yang setidaknya menurut Quraisy Shihab terdapat dua

23 Tasbih, "Kedudukan dan Fungsi Kaidah-Kaidah Tafsir," Jurnal Farabi Vol. 10 no. 1 Juni 2013, 107.

24 Sahabat dibagi menjadi dua, yakni sahabat dalam pengertia sebenarnya dan sahabat kecil. Sahabat kecil adalah mereka yang dapat memahami petunjuk Al-Qur'an walaupun pemahamannya dari segi bahasa/makna tidak sepenuhnya sama dengan pemahaman para sahabat yang bersama nabi Saw. menyaksikan turunnya Al-Qur'an dan peristiwa-peristiwa yang menyebabkannya turun. M. Quraisy Shihab, "Ibnu Jarir al-Tabariy," Ulumul Qur'an No. 1, 1989, 40. Sedangkan sumber tafsir para sahabat ada tujuh, yakni 1) Al-Qur'an al-Karim, 2) Sunnah Nabi Muhammad S.A.W. 3) Bahasa Arab, 4) Ahl al-Kitab, 5) Pemahaman dan ijtihad, 6) Mengambil tafsir sahabat lain, 7) Menafsir ayat berdasar situasi dan kondisi ketika ayat itu turun. Yusuf Qardhawi. 1997. AlQur'an dan As Sunnah: Referensi Tertinggi Umat Islam. terj. Jakarta: Rabbani Pers, hlm. 96.

25 Said Agil Husin Al Munawar. AlQur'an Membangun Tradisi Kesalehan Hakiki. hlm. 79 . kekurangan. Pertama, terjerumusnya sang mufassir dalam uraian kebahasaan dan kesasteraan yang bertele-tele, sehingga pesan pokok Al-Qur'an menjadi kabur. Kedua, sering kali konteks turunnya ayat (uraian $a s b a b$ an nuzul atau situasi kronologis turunnya ayat-ayat hukum yang dipahami dari uraian nasikh-mansukh) hampir dapat dikatakan terabaikan sama sekali, sehingga ayat tersebut bagaikan turun bukan dalam suatu masa atau berada di tengah-tengah masyarakat tanpa budaya. $^{26}$

Berbeda dengan Quraisy Shihab, Said Agil Husin Al-Munawwar menyebutkan kelemahan dalam tafsir $b i$ al ma'tsur diantaranya adalah terbatasnya persediaan riwayat yang merupakan tafsir ayat-ayat Al-Qur'an, sehingga tidak terlalu banyak diharapkan untuk menjawab berbagai problem yang dihadapi masyarakat dari masa ke masa. Selain hadis-hadis yang ada pun masih memerlukan penelitian yang amat cermat karena masih banyak tercampur dengan cerita israi'iliyat. $^{27}$ Ini menandakan perlu adanya upaya keras guna "mereproduksi" tafsir bi al ma'tsur yang sesuai dengan perkembangan zaman. Tentunya berdasarkan pada Al-Qur'an yang disesuaikan dengan konteks kontemporer, agar penafsiran Al-Qur'an dengan menggunakan metode ini benar-

26 M. Quraisy Shihab. 2012. Membumikan Al-Qur'an: Fungsi dan Peran Wahyu dalam Kehidupan Masyarakat. Bandung: Mizan, hlm. 84.

27 Said Agil Husin Al Munawar. AlQur'an Membangun Tradisi Kesalehan Hakiki. 79. 
benar dapat menjawab perkembangan dunia modern.

Selain berbagai kelemahan yang disebutkan di atas, Said Agil Husin AlMunawwar juga mengemukakan bahwa tafsir bi al ma'tsur juga memiliki kelemahan yang lain. Kelemahankelemahan tersebut di antaranya adalah

1. Banyaknya riwayat yang disiapkan oleh musuh Islam, seperti orang zindiq, baik dari Yahudi maupun Nasrani.

2. Bercampur-baurnya riwayat yang shahih dengan yang tidak shahih, juga banyaknya perkataan yang dibangsakan kepada sahabat dan tabi'in tanpa seleksi, sehingga tercampurlah hal yang hak dan bathil.

3. Adanya riwayat-riwayat israi'iliyat yang mengandung dongeng dan hal itu tidak dapat dibenarkan.

Bahkan menurut H. Sodiq Ihsan, kelemahan tafsir bi al ma'tsur juga dapat dilihat dari :

4. Masuknya orang-orang zindiq ke dalam Islam dari Yahudi, Nasrani, dan Romawi yang tidak bisa meninggalkan budaya aslinya dan dengan latar belakang serta motivasi tertentu.

5. Perpecahan dan perebutan kekuasaan politik, tiap kelompok berusaha untuk membela anggotanya dan pendirinya, lalu menafsirkan ayat-ayat tertentu untuk kepentingan golongannya.

Selain hal ini, sebagai tambahan, Mahmud Basuni Faudah mengemukakan kelemahan tafsir $b i$ al ma'tsur di antaranya:

6. Fanatik kemadzhaban; yang mana setiap golongan berusaha mendukung madzhabnya dengan segala cara sekalipun dengan cara melakukan pemalsuan hadis Rasulullah S.A.W.

7. Corak politik; yang mana terdapat banyak sekali riwayat-riwayat palsu yang nisbatkan kepada Ali dan Abbas.

8. Glora semangat musuh-musuh Islam; yang mana sebagian mereka masuk Islam, sementara hati mereka penuh dengan tipu daya terhadap Islam. $^{28}$

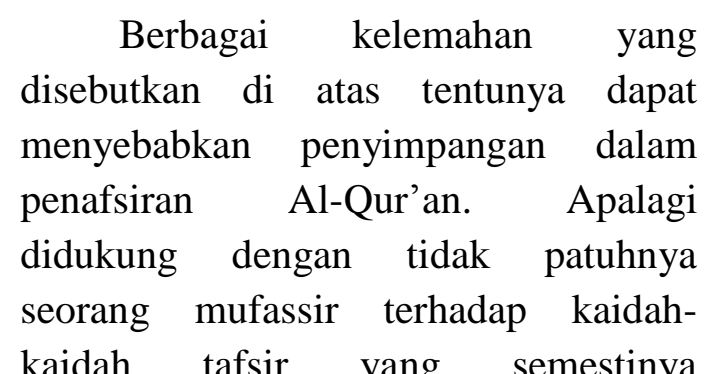
diterapkan. Sebagaimana komponen kaidah tafsir yang dikemukakan oleh Quraisy Shihab, yakni adanya ketentuan-ketentuan yang harus diperhatikan dalam menafsirkan AlQur'an, sistematika yang hendak ditempuh dalam menguraikan penafsiran, serta patokan-patokan khusus yang bisa membantu pemahaman ayat-ayat Al-Qur'an, baik dari ilmu bantu seperti bahasa dan ushul fiqh maupun yang ditarik langsung dari penggunaan Al-Qur'an. ${ }^{29}$ Lolosnya

${ }^{28}$ Said Agil Husin Al Munawar. AlQur'an Membangun Tradisi Kesalehan Hakiki. hlm. 79-80.

${ }^{29}$ Ahmad Izzan. 2011. Metodologi Ilmu Tafsir. Bandung: Tafakur, hlm. 121. Kaidahkaidah Tafsir tersebut harus memperhatikan tiga sumber utama, yakni a) disiplin ilmu tertentu, seperti ilmu bahasa, ushul fiqh dan teologi. b) Kesadaran tentang perlunya mengikat diri agar tdak terjerumus dalam kesalahan. c) Kaidah yang ditarik dari dan bersumber lansung dari pengamatan terhadap Al-Qur'an, baik yang tidak berkaitan dengan satu disiplin ilmu, maupun yang tidak sejalan dengan kaidah- 
seorang mufassir dari hal tersebut dapat berakibat pada penyimpangan dalam Al-Qur'an.

Penyimpangan yang terjadi dapat mengakibatkan para pembaca tafsir keliru dalam memahami maksud dari ayat yang ditafsirkan. Lebih jauh lagi dan yang lebih mengkhawatirkan, para pembaca tafsir justru mendapatkan informasi dan pengetahuan yang bertentangan dengan makna yang sesungguhnya.

\section{Kritik terhadap Tafsir bi ar Ra'yi}

Tafsir bi ar ra'yi adalah tafsir yang kedudukannya berada setelah tafsir bi al ma'tsur. Tafsir ini lahir sebagai akibat adanya tuntutan AlQur'an yang berulang kali menyebutkan kata-kata yang bermakna agar manusia menggunakan akal pikiran dalam memahami berbagai ayat yang terkandung di dalamnya. Perintah tersebut kemudian memunculkan tafsir yang dikenal sebagai tafsir bi ar ra'yi atau ijtihad. Sebuah metode tafsir yang dalam menafsirkan Al-Qur'an didominasi oleh $a r-r a ' y u$ daripada alma'tsur. ${ }^{30}$ Pada metode penafsiran ini

kaidah disiplin ilmu. Baca lebih lanjut dalam M. Quraisy Shihab. Kaidah Tafsir, Syarat, Ketentuan, dan Aturan yang Patut Anda Ketahui dalam Memahami Ayat-Ayat AlQur'an. hlm. 16-17.

30 Apabila sebuah kitab tafsir lebih didominasi oleh tafsir bi ar ra'yi dan ijtihad, sementara tafsir bi al ma'tsur hanya sedikit, maka tafsiran yang demikian itu dinamakan tafsir bi ar ra'yi. Said Agil Husin Al Munawar. Al-Qur'an Membangun Tradisi Kesalehan Hakiki. hlm. 81. Sedang Adz Zahabi menyebutkan bahwa tafsir bi ar ra'yi adalah tafsir ayat-ayat Al-Qur'an yang didasarkan kepada ijtihad para mufassirnya dan menjadikan penggunaan $r a^{\prime} y u$ sangat dominan, akan tetapi hal ini berakibat pada munculnya khilafiyah. Sebab setiap orang memiliki pemikiran dan latar belakang yang berbeda, sehingga perbedaan pendapat sangat mungkin terjadi.

Benih-benih perbedaan pendapat dan pemahaman sebagai dampak dari penggunaan $r a ' y u$ dalam penafsiran AlQur'an mengakibatkan munculnya berbagai madzhab. Madzhab tersebut berbeda satu dengan yang lain. Ini bermakna bahwa terdapat ketidaksamaan pemikiran pada ulamaulama tafsir dan orang-orang yang menafsirkan Al-Qur'an. Sisi positif dari banyaknya madzhab dalam penafsiran Al-Qur'an adalah bahwa para pembaca disuguhkan berbagai pilihan tafsir dari Al-Qur'an. Akan tetapi, terdapat pula sisi negatif dari banyaknya madzhab yang muncul atas penafsiran Al-Qur'an, yakni eksklusifitas dan fanatisme kelompok atau golongan terhadap madzhab tertentu. Ini dapat berakibat pada munculnya anggapan madzhab tafsir yang dianut adalah yang paling benar, sehingga tidak menutup kemungkinan menyalahkan madzhab yang lain. Padahal, produk penafsiran Al-Qur'an sifatnya bukan absolut karena di dalamnya melibatkan unsurunsur penalaran, kajian, ijtihad para mufassir yang didasarkan pada kemampuan yang dimiliki, sehingga sewaktu-waktu dapat ditinjau kembali. ${ }^{31}$

akal fikiran sebagai pendekatan utamanya. Muhammad Husein Adz Zahabi. 1986. Tafsir wa al-Mufassirun. Bairut: Dar al Fikr, hlm. 255.

31 Baca juga Arie Muchlina Amri. "Metode Penafsiran Al-Quran," Jurnal Insyiah Vol. 2 No. 1, 3. 
Tudingan-tudingan yang menyalahkan madzhab tafsir yang lain selain dari yang dipegang olehnya dan fanatisme golongan dapat berakibat pada penyimpangan dalam tafsir. Sebab eksklusifitas yang terbangun tersebut menjadikan penganut madzhab menolak pemikiran atau penafsiran Al-Qur'an dari madzhab yang lain, yang mungkin lebih mendekati maksud dan makna kandungan Al-Qur'an yang sesungguhnya.

Tafsir ijtihad yang merupakan hasil dari ijthad mufassir, tafsir bi ar ra'yi tentu memiliki berbagai kelemahan. Kelemahan inilah yang oleh beberapa kalangan diuraikan sebagai sebuah perhatian penting bagi tafsir bi ar ra'yi. Said Agil Husin Al-Munawar mengemukakan bahwa bila seseorang ingin menelusuri kesalahan-kesalahan yang terdapat dalam tafsir bi ar ra'yi sampai kepada faktor-faktor yang menyebabkannya, dapat dikembalikan kepada dua faktor penting:

1. Mufassir yang bersangkutan meyakini kebenaran salah satu di antara banyak makna yang ada, kemudian menggunakan makna tersebut untuk menerangkan berbagai lafadz Al-Qur'an.

2. Mufassir yang bersangkutan berusaha menafsirkan AlQur'an berdasarkan makna yang dimengerti penutur bahasa Arab semata tanpa memperhatikan siapa yang berbicara dengan (menggunakan) Al-Qur'an itu, kepada siapa diturunkannya Al-
Qur'an dan siapa pula yang dibicarakan Al-Qur'an itu. ${ }^{32}$

Poin pertama dalam penjelasan yang disampaikan Said Agil Husin Al Munawar di atas seolah memberikan pemahaman bahwa mufassir dalam tafsir bi ar ra'yi bisa saja terjebak pada ekslusifitas sebuah pemahaman yang dianggap benar olehnya. Ini dilakukan dengan mengabaikan kemungkinan pemahaman yang lain. Oleh karena itu, mufassir dengan tipologi ini kemudian membawa pemahaman tersebut untuk menerangkan ayat-ayat Al-Qur'an. Sepintas tidak ada yang salah dengan hal demikian, akan tetapi hal ini dapat menjadi sebuah kesalahan bila pemahaman yang dibawa oleh seorang mufassir tersebut mengabaikan berbagai kemungkinan yang dapat membawa seseorang pada pemahaman makna sesungguhnya yang dimaksud dalam Al-Qur'an.

Pada poin kedua yang dijelaskan oleh Said Agil Husin Al-Munawar di atas, para mufassir dengan tipologi ini memiliki kecenderungan untuk menggunakan penafsiran sesuai dengan bahasa Arab yang dipahami oleh banyak penutur bahasa itu. Sedangkan aspek penting yang lebih utama tidak menjadi fokus perhatian mufassir ini, seperti siapa yang sedang berbicara di dalam Al-Qur'an, kepada siapa ia diturunkan, dan siapa yang dibicarakan di dalamnya. Maka, tatkala aspek ini tidak diperhatikan oleh mufassir, ia akan terjebak pada kaidah-kaidah dalam

32 Said Agil Husin Al Munawar. AlQur'an Membangun Tradisi Kesalehan Hakiki. hlm. 79-88. 
bahasa Arab semata, tanpa melihat penting aspek-aspek yang disebutkan tadi. Padahal, Ibnu Abbas mengemukakan bahwa bila seorang menemui kesulitan dalam menafsirkan Al-Qur'an, maka hendaklah melakukan penelitian (melihat) pada syair-syair, karena syair-syair tersebut adalah sastra Arab kuno. Dan di dalam Al-Qur'an telah ditetapkan adanya sebagian kalimat mu'arabah (kata-kata asing yang diarabkan). ${ }^{33}$ Artinya, dapat menggunakan aspek lain selain bahasa Arab modern, begitu pula dengan aspek yang lain.

Selain perlunya melihat aspekaspek yang ada di atas, hal terpenting apabila seseorang ingin menggunakan tafsir bi ar ra'yi adalah tidak melepaskan tafsir bi ar ra'yi dari tafsir bi al ma'tsur. Menurut Said Agil Husin Al Munawar, sulit, bahkan keliru apabila seorang hanya mengandalkan ra'yunya tanpa menggunakan tafsir bi al ma'tsur yang merupakan dasar dari tafsir. ${ }^{34}$ Ini berarti, untuk mendapatkan pemahaman terhadap Al-Qur'an yang komprehensif diperlukan penguasaan tidak hanya satu metode tafsir tetapi juga menggunakan metode tafsir yang lain.

\section{E. Penyebab Penyimpangan dalam Tafsir}

Berbagai kelemahan yang ada pada tafsir bi al ma'tsur, tafsir bi ar

${ }^{33}$ Kahyar Masyhur. 1992. Pokok-pokok Ulumul Qur'an. Jakarta: Rineka Cipta. hlm. 173.

34 Said Agil Husin Al Munawar. AlQur'an Membangun Tradisi Kesalehan Hakiki. hlm. 81. ra'yi dan tafsir bi isyari menjadi peluang munculnya berbagai bentuk penyimpangan.

Penyimpanganpenyimpangan tersebut tidak bisa dihindari, sebab kelemahan yang ada pada metode penafsiran akan menjadi jalan bagi penyimpangan tersebut untuk muncul. Meski tafsir adalah sebuah disiplin ilmu yang digunakan untuk memahami Al-Qur'an, bukan berarti kitab suci tersebut terbebas dari berbagai macam kepentingan. ${ }^{35}$ Sebaliknya, semakin banyak kepentingan yang bisa muncul dengan menggunakan kitab suci sebagai alat legitimasinya. Bisa kepentingan politik, ekonomi, ke-madzhab-an, bahkan kepentingan orang-orang yang memusuhi Islam. Oleh sebab itu, perlu diketahui hal apa saja yang menyebabkan penyimpangan dalam tafsir.

\section{Penyimpangan-penyimpangan}

yang terjadi dalam penafsiran AlQur'an memiliki beberapa fakor. Quraisy Shihab menyebut setidaknya terdapat enam faktor yang menjadi penyebab penyimpangan dalam tafsir

${ }^{35}$ Ilmu ini memudahkan seseorang dalam memahami makna dan kandungan yang terdapat dala setiap ayat Al-Qur'an, utamanya ayat-ayat yang muhkam. Berisi metode yang menjelaskan berbagai seluk-beluk Al-Qur'an, sehingga kehadiran ilmu ini begitu diperlukan. Mengingat begitu pentingnya ilmu tafsir, setiap mufassir yang hendak menafsirkan Al-Qur'an wajib menguasai ilmu ini. Akan tetapi, dalam praktinya, tidak semua yang menyebut dirinya sebagai mufassir memiliki hak dan dan kemampuan serta bertanggungjawab dalam menafsirkan Al-Qur'an. Akibatnya, lahir berbagai bentuk penyimpangan yang mengakibatkan kaburnya makna yang sesungguhnya terkandung dalam ayat AlQur'an. 
Al-Qur'an. Pertama, subjektifitas mufassir. Kedua, kekeliruan dalam menetapkan metode atau kaidah. Ketiga, kedangkalan dalam ilmu-ilmu alat yang seharusnya dikuasai. Keempat, kedangkalan pengetahuan tentang materi uraian (pembicaraan) ayat. Kelima, tidak memperhatikan konteks, baik asbab an nuzul, hubungan antar ayat, maupu kondisi sosial masyarakat. Keenam, tidak memperhatikan siapa pembicara dan terhadap siapa pembicara itu ditujukan. ${ }^{36}$ Keenam faktor ini menjadi penyebab penyimpangan penafsiran dalam AlQur'an.

Selain enam faktor di atas, juga terdapat faktor lain yang perlu diperhatikan. Faktor pertama adalah adanya kesamaran makna ayat yang semakin bertambah ketika umat Muslim semakin jauh dari masa nabi dan sahabat. Penafsiran Al-Qur'an pun semakin bertambah banyak seiring semakin bertambahnya kesamaran makna ayat, sehingga ayat-ayat AlQur'an ditafsirkan secara keseluruhan. ${ }^{37}$ Jarak antara Nabi Muhammad S.A.W. dengan umat Islam pada saat ini telah mencapai 14 abad. Ini sekaligus menjadi sebuah pertanda bahwa

36 M. Quraisy Shihab. 1997. Membumikan Al-Qur'an: Fungsi dan Peran Wahyu dalam Kehidupan Masyarakat. Bandung: Mizan, hlm. 79.

Ash Shidieqy menyebutkan hal tersebut sebagai salah satu bentuk karakteristik tafsir pada masa sahabat. Akan tetapi, ini dapat menjadi sebuah pendapat yang berlaku pula bagi terjadinya penyimpangan dalam tafsri. Baca juga Muhammad Hasbi Ash Shidieqy. 1997. Sejarah dan Pengantar Ilmu Al-Qur'an dan Tafsir. Semarang: PT. Pustaka Rizky Putra, hlm. 198. semakin jauh jarak kehidupan umat dari pemegang otoritas tafsir, maka akan semakin banyak tafsir yang. Artinya, kebenaran dan kekeliruan, apalagi penyimpangan dalam tafsir amat sangat mungkin terjadi.

Distorsi dalam penafsiran AlQur'an bisa saja terjadi antara satu generasi dengan generasi yang lain. Sebagaimana penafsiran Al-Qur'an yang dilakukan oleh Rasulullah S.A.W. yang kemudian diadopsi oleh para sahabat dan diajarkan kepada generasi berikutnya. Akan tetapi, meski objek penafsirannya sama, yakni Al-Qur'an, namun subjek yang menafsirkan AlQur'an berbeda satu dengan yang lain. Rasulullah S.A.W., para sahabat, tabiin dan ulama-ulama tafsir yang lain ternyata memiliki perbedaan penafsiran. Sebagaimana tafsir yang dilakukan oleh para sahabat terdapat perbedaan dengan tafsir yang dilakukan oleh tabi'in, begitu pula dengan ulama-ulama tafsir yang klasik maupun kontemporer. ${ }^{38}$

Faktor kedua yang menyebabkan terjadi penyimpangan dalam tafsir adalah berada pada diri mufassir sendiri. Mufassir tidak akan dapat melepaskan diri dari subjektifitas, karena dia sendiri adalah subjek yang melakukan penafsiran. $^{39}$ Artinya, latar belakang

38 As-Shiddieqy mengemukakan bahwa tafsir tabiin memiliki beberapa ciri diantaranya adalah sudah terdapat israiliat dalam penafsiran Al-Qur'an, muncul benih-benih perbedaan madzhab dan terdapat banyak perbedaan pendapat antara tabiin dengan sahabat. Muhammad Hasbi As-Shiddieqy, Sejarah dan Pengantar Ilmu Al-Qur'an dan Tafsir. hlm. 203.

39 Seorang mufassir tidak dapat melepaskan diri dari subjektifitas pribadi. Ini disebabkan mufassir adalah subjek yang melakukan penafsiran, sehingga ia akan 
para mufassir seperti sosial, politik, budaya, pendidikan, fanatisme madzhab, kepentingan dan keingingan sangat berpengaruh dalam mewarnai tafsir yang dihasilkan. Meski Quraisy Shihab menyebut hal ini sebagai latar belakang yang dimiliki oleh seorang mufassir, akan tetapi keberpihakan yang berlebihan terhadap latar belakang yang dimiliki oleh seorang mufassir tentu dapat berakibat tidak baik. ${ }^{40}$ Sebagai contoh, masuknya orang-orang di luar Islam seperti Yahudi, Nasrani, dan Romawi ke dalam Islam yang membawa serta budaya mereka dan latar belakang, juga motivasi yang lain. Tidak hanya itu, perpecahan dan perebutan kekuasaan politik melahirkan fanatisme golongan, sehingga pembelaan yang dilakukan oleh orangorang tertentu kepada anggota dan pendiri kelompok dengan cara menafsirkan ayat Al-Qur'an sesuai dengan kepentingan mereka. ${ }^{41}$

membawa serta latar belakang yang ada pada dirinya dalam menafsirkan Al-Qur'an. Latar belakang budaya, politik, sosial, dan lingkungan kesehariannya mempengaruhi pola pikir yang ada pada diri mufassir. Ini bermakna bahwa mufassir tidak akan bisa terlepas dari latar belakang yang melatar kehidupannya dalam menafsikan Al-Qur'an.

${ }^{40}$ Quraisy Shihab mengemukakan bahwa seorang mufassir yang memeliki kecenderungan ilmu hukum, maka tafsirnya banyak berbicara tentang hukum. Begitu juga jika seorang mufassir kecenderungannya filsafat, maka tafsir yang dihidangkan bernuansa filosofis, demikian seterusnya. M. Quraisy Shihab. 2002. Tafsir Al Misbah: Pesan, Kesan dan Keserasian AlQur'an. Jakarta: Lentera Hati, Vol. 2, vii.

41 Lihat dalam Said Agil Husin Al Munawar. Al-Qur'an Membangun Tradisi Kesalehan Hakiki. 80. Shalah 'Abd al-Fattah alKhalidi berpendapat bahwa para orientalis yang menekuni islamic studies turut serta dan ambil bagian dalam penafsiran Al-Qur'an. Mereka
Kemampuan yang beragam pada diri para mufassir juga mengakibatkan adanya stratifikasi penafsiran. Kemampuan yang mumpuni yang dimiliki oleh seorang mufassir akan terlihat lebih menonjol daripada mufassir yang menafsirkan ayat AlQur'an dengan kemampuan yang standar. Penguasaan ilmu-ilmu alat pun menjadi perhatian yang cukup serius bagi orang-orang yang hendak menafsirkan Al-Qur'an. Lebih lagi mufassir yang ingin menggunakan metode tafsi bi ar ra'yi dalam menafsirkan Al-Qur'an. ${ }^{42}$ Maka, bukan sebuah hal yang tabu apabila mufassir dari generasi kontemporer sering mengungkapkan kalimat "dengan segala kelemahan dan kelebihan yang terdapat pada diri mufassir terdahulu", dalam memberikan penilaian kepada mufassir sebelumnya.

lebih menggunakan tafsir al-maudhu' $i$ dibanding dengan metode tafsir yang lain. Pada satu sisi, hal ini menambah khazanah keilmuan tafsir Al-Qur'an, tetapi di sisi lain penyimpangan dalam tafsri Al-Qur'an pun terbuka untuk dilakukan oleh orientalis, sebab orientalis tetaplah bukan seorang Muslim, dan kepentingan-kepentingan di luar kepentingan Islam pun dapat muncul.

42 Selain penguasaan ilmu alat, adalah syarat lain yang harus dipenuhi oleh orangorang yang hendak menafsirkan Al-Qur'an dengan tafsir bi ar ra'yi di antaranya: a) mengetahui sebab nuzul, nasikh-mansukh, ilmu qiraat, dan syarat-syarat keilmuan lainnya. b) Tidak menafsirkan hal-hal yang merupakan otoritas Tuhan untuk mengetahuinya. c) Tidak menafsirkan ayat-ayat berdasarkan hawa nafsu dan interes pribadi. d) Tidak menafsirkan ayat berdasarkan aliran atau paham yang jelas batil dengan maksud justifikasi terhadap paham tersebut. d) Tidak menganggap bahwa tafsirnya itu paling benar tanpa argumentasi yang pasti. Dalam Said Agil Husin Al Munawar. AlQur'an Membangun Tradisi Kesalehan Hakiki. hlm. 81 . 
Pernyataan Adz Dzahabi memberikan penjelasan yang baik terkait dengan kemampuan seseorang dalam menafsirkan Al-Qur'an. Meski ia menjelaskan dalam konteks penafsiran yang dilakukan oleh para sahabat, namun Adz Dzahabi memberikan pemahaman yang lebih akan hal ini. Ia mengemukakan bahwa kemampuan menafsirkan Al-Qur'an yang dimiliki seseorang berbeda satu dengan yang lain. Utamanya pada sahabat. Lebih lanjut ia menyatakan bahwa sahabat tidak memiliki kemampuan yang sama dalam memahami Al-Qur'an, bahkan tingkat pemahaman mereka berbedabeda. Terdapat sebuah ungkapan AlQur'an yang dapat dipahami oleh salah seorang sahabat, tetapi juga terdapat sahabat lain yang tidak dapat memahami ungkapan tersebut. Hal ini disebabkan kapasitas intelektual mereka yang berbeda-beda. Sementara berbagai hal yang terkait dengan Al-Qur'an seperti aspek-aspek yang terkait dengannya dan ketidakjelasan makna ayat menjadi faktor yang mempengaruhi juga. $^{43}$

Faktor ketiga yang menjadi penyebab penyimpangan dalam tafsir adalah dari sisi materi. Materi yang dimaksud bukanlah teks Al-Qur'an, melainkan penafsir yang kurang cermat dalam menafsirkan materi yang terkait dengan penafsiran Al-Qur'an. Seperti mendahulukan yang mutlaq daripada muqayyad, tidak memperhatikan kaitan ayat yang satu dengan yang lain (munasabah), tidak menguasai masalah

43 Muhammad Husein Adz Dzhahabi. 1976. al-Tafsir wa al-Mufassirun Vol I. Beirut: Dar Ilya al-Turath al-Arabi, hlm. 34. yang ditafsirkan, mendahulukan yang mutasyabihat dari yang muhkam, tidak memperhatikan siapa yang berbicara dan yang sedang dibicarakan, hingga kesalahan dalam penggunaan metode dapat menyebabkan penyimpangan dari sisi materi. Materi yang seharusnya berada pada posisi tertentu kemudian bergeser, tidak berurut dan tidak semestinya mengakibatkan tafsir yang dilakukan dapat menyimpang dari seharusnya.

Penyimpangan yang lain terjadi berdasarkan faktor yang keempat, yakni faktor historis. Sebagaimana perkembangan tafsir Al-Qur'an yang dilakukan dengan menggunakan dua tahapan, yakni tahapan periwayatan dan tahapan pembukuan. Pada tafsir bi al ma'tsur penyimpangan dapat terjadi dengan dihapusnya isnad-isnad dan orang mengutip tafsir tersebut dengan menghilangkan sanad-sanad. Penghilangan sanad ini dapat berakibat pada kurangnya data bagi mufassir selanjutnya, serta pembaca tidak memahami siapa yang meriwayatkan ayat-ayat yang ditafsirkan. Ketiadaan sanad dapat mengakibatkan munculnya peluang bagi orang-orang yang berniat jahat dengan memunculkan cerita-cerita israi'iliyat yang sesungguhnya bertentangan dengan akal, namun diklaim bersumber dari nabi Muhammad S.A.W. Padahal ini dilakukan untuk menonjolkan ambisi pribadi atau kelompok semata. Lebih dari itu, dampak yang ditimbulkan adalah banyaknya umat Islam yang "tercemar" cerita-cerita israi'iliyat yang bertentangan dengan Al-Qur'an dan 
Sunnah, sehingga semakin terpaling dari keduanya.

Keingintahuan untuk mencari penjelasan yang lebih detail tentang AlQur'an dengan menggunakan kisahkisah isra'iliyat, dapat berkaibat pada penyimpangan dalam tafsir. Hal ini disebabkan isra'iliyat tidak selalu membawa seseorang untuk sampai pada makna ayat yang sesungguhnya. Lebih dari itu, ia justru dapat menjauhkan seseorang dari ayat yang ditafsirkan. Oleh karenanya, perlu adanya sikap yang pasti terhadap isra'iliyat tersebut. Terkait hal ini, para cendekiawan sepakat dalam menyikapi kisah-kisah Isra'iliyat. Pertama, bahwa kisah-kisah Isra'iliyat yang sejalan dengan AlQur'an dan sunnah, maka ia dibolehkan. Kedua, kisah-kisah Isra'iliyat yang bertentangan dengan Al-Qur'an dengan sunnah, maka harus ditinggalkan dan tidak boleh diambil. Dan, ketiga, bersikap tawaquf, artinya tidak menerima sepenuhnya cerita-cerita isra'iliyat dan tidak pula menolak sepenuhnya cerita-cerita tersebut.

Sedangkan dalam tafsir bi ar ra'yi faktor historis yang mengakibatkan penyimpangan dalam tafsir ini adalah kecenderungan terhadap madzhab teologis yang tidak dengan mudah dapat dihilangkan. Pengaruh pengalaman bermadzhab justru dapat menjadi faktor penyebab penyimpangan dalam tafsir. Meski terkesan sederhana, namun peyimpangan dalam penafsiran AlQur'an dapat berakibat pada sesuatu yang membahayakan. Penyimpangan dalam tafsir dapat menyebabkan tafsir yang menyimpang. Hal ini disebabkan adanya kriteria tafsir yang dilanggar oleh orang yang menafsirkan AlQur'an. Lebih dari itu, tidak hanya tafsir yang menyimpang, tetapi juga dapat menyesatkan pembacanya.

Ash Shiddieqy berpendapat bahwa bila seseorang fokus terhadap satu metode dalam menafsirkan AlQur'an seperti tafsir yang dilakukan oleh para tabiin yang lebih menggunakan pendekatan/metode riwayah, maka akan muncul beberapa kelemahan. Di antara kelemahankelemahan tersebut adalah terjerumusnya sang mufassir dalam uraian kebahasaan dan kesusasteraan yang bertele-tele, sehingga pesan pokok Al-Qur'an menjadi kabur di celah uraian itu. Selain ini, acapkali konteks turunnya ayat hampir dapat dikatakan terabaikan sama sekali, sehingga ayatayat tersebut bagaikan turun bukan dalam satu masa atau berada di tengahtengah masyarakat tanpa budaya. ${ }^{44}$ Oleh karenanya, konteks turunnya Al-Qur'an (asbab an nuzul) tidak dapat dipisahkan dari penafsiran Al-Qur'an.

\section{F. Bentuk-Bentuk Penyimpangan dalam Tafsir}

Faktor-faktor yang menyebabkan lahirnya penyimpangan dalam tafsir bukanlah sebuah hal yang tidak akan terjadi. Sebaliknya, penyimpangan tersebut telah terjadi dengan beragam bentuk. Di antara beragam bentuk penyimpangan tafsir, penulis mengkelompokkannya dalam beberapa

\footnotetext{
${ }^{44}$ Muhammad Hasbi Ash Shiddieqy. 1965. Sejarah dan Pengantar Ilmu Al-Qur'an dan Tafsir. TKT: Bulan Bintang. hlm. 202.
} 
bentuk, yakni penyimpangan dalam tafsir historis, penyimpangan dalam tafsir teologi, penyimpangan dalam tafsir sufi, penyimpangan dalam tafsir linguistik, penyimpangan dalam tafsir ilmi, dan penyimpangan dalam tafsir modern.

\section{Penyimpangan dalam Tafsir Historis $^{45}$}

Sosio-naratif yang ini dimimiliki oleh Al-Qur'an adalah keringkasan dalam menuturkan kisah-kisah. AlQur'an tidak memberikan perincian jalannya kisah, melainkan hanya memilih fragmen yang berkaitan dengan substansi tema yang berisi perjalanan. Akan tetapi, justru dari sanalah muncul penimpangan-prnyimpangan dalam historis. Para sejarawan yang menulis jenis tafsir ini lupa bahwa penekanan kisah-kisah Al-Qur'an tidak terletak pada jalan ceritanya, tetapi pada aspek pesan moral yang dikandungnya. Dengan demikian adalah suatu penyimpangan ketika kisah-kisah AlQur'an ditafsirkan dengan perincian yang tidak substansial.

Penyimpangan dalam tafsir historis lebih jelas lagi ketika tafsir itu dimasuki Isra'iliyat, yakni legendalegenda Yahudi dan Nasrani yang masuk ke dalam tafsir. Lebih parah lagi ketika Isra'iliyat yang dimasukkan ke dalam tafsir masuk dalam kategori maudhu' (palsu). Adz-Dzahabi

\footnotetext{
${ }^{45}$ Rosihon Anwar. 2009. Pengantar
} Ulumul Qur'an. Bandung: Pustaka setia, dalam Raden Luhur, "Penyimpangan Al-Qur'an," https://radenluhur.wordpress.com/2016/ 06/24/makalah-penyimpangan-al-quran/ (diakses pada tanggal 18 September 2017). menyebut bahwa tafsir Al-Khazin banyak dipenuhi Isra'iliyat jenis itu, kitab tafsir lain semacam tafsir Ibnu Katsir, Tafsir Ath-Thabari, Tafsir Muqatil bin Sulaiman, Ruh Al-Ma'ani, dan Al-Manar pun diduga kuat memuat pula riwayat-riwayat Isra'iliyat.

Eksistensi Israi'iliyat dalam tafsir historis tidak saja merupakan penyimpangan, bahkan Muhammad Syaltut menyebut telah menjauhkan umat Islam dari mutiara-mutiara AlQur'an. Contoh yang menarik adalah ketika menjelaskan kisah penyembelihan sapi (baqarah) oleh Bani Israil, para sejarawan terlena denan cerita-cerita Isra'iliyat hingga lupa akan pesan moral yang ada di balik kisah tersebut.

2. Penyimpangan dalam Tafsir Teologi ${ }^{46}$

Skisma aliran-aliran teologi ternyata tidak selamanya membawa rahmat. Pada moment tertentu ini justru dapat melahirkan peyimpangan dalam tafsir teologi. Aliran ini kerapkali melakukan pemutarbalikan ayat guna disesuaikan dengan doktrin madzhab yang dianutnya. Al-Qur'an tidak dijadikan sebagai sumber pelerai perselisihan teologi, sebaliknya, ia dijadikan sebagai justifikasi bagi madzhabnya masing-masing. Tentu hal ini akan melahirkan penyimpangan dalam penafsiran Al-Qur'an.

46 Lihat Rosihon Anwar. 2009. Pengantar Ulumul Qur'an. Bandung: Pustaka setia, dalam Raden Luhur, "Penyimpangan AlQur'an,". 
Untuk mempertahankan doktrin "ketidakmunkinan" Allah S.W.T. dapat dilihat di akhirat kelak, Zamaksyari (tokoh besar Mu'tazilah) "terpaksa" harus melakukan takwil (metefora) terhadap ayat yang jelas-jelas bertentangan dengan doktrin Mu'tazilah. Hasan Al-Asykari, tokoh Syi'ah, mengarahkan penafsiran terhadap surat Al-Baqarah [2] : 163 untuk menjustifikasikan doktrin "taqqiyah". 47 Aliran Khawarij pun tidak ketinggalan menjadikan Al-Qur'an surat Al-Maidah [5]: 44 untuk mempertahankan doktrinnya bahwa “orang yang fasik adalah kafir". ${ }^{8}$ Ayat-



"Dan Tuhanmu adalah Tuhan Yang Maha Esa; tidak ada Tuhan melainkan Dia Yang Maha Pemurah lagi Maha Penyayang”.(QS. Al Baqarah [2]: 163)

${ }^{48}$ QS. Al Maidah [5] : 44

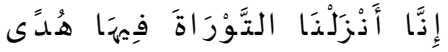

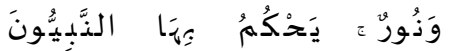

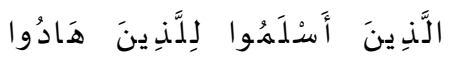

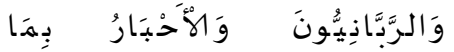

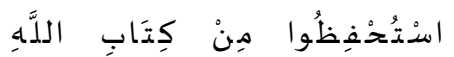

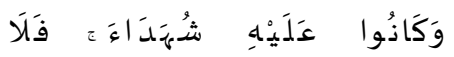

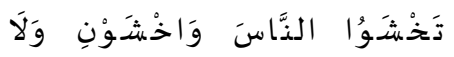

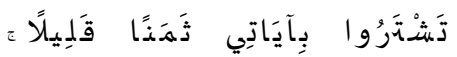

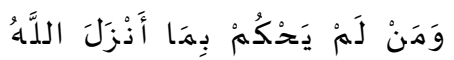

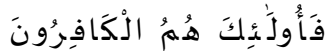

$$
\begin{aligned}
& \text { "Sesungguhnya Kami telah }
\end{aligned}
$$

ayat lain disimpangkan oleh kelompok Jabbariyah untuk mempertahankan doktrin "determinismenya". Begitulah selanjutnya, masing-masing aliran teologi mempunyai andil dalam melakukan penyimpanganpenyimpangan.

\section{Penyimpangan dalam Tafsir Sufi ${ }^{49}$}

Tafsir sufi dimaknai sebagai sebuah tafsir yang menggunakan pendekatan eksoterik dalam menjelaskan maksud dari ayat-ayat Al-Qur'an. Pendekatan ini kemudian dikuatkan dengan isyaratisyarat yang didapatkan oleh seorang sufi melalui suluknya. Tafsir ini bersifat ekslusif, yang kemudian banyak mendistorsi ayat-ayat Al-Qur'an. Ia terdiri dari beberapa corak, yakni corak toeretis (an-nazhari), simbolik (isyari),

\footnotetext{
diputuskan perkara orangorang Yahudi oleh nabi-nabi yang menyerah diri kepada Allah, oleh orang-orang alim mereka dan pendeta-pendeta mereka, disebabkan mereka diperintahkan memelihara kitab-kitab Allah dan mereka menjadi saksi terhadapnya. Karena itu janganlah kamu takut kepada manusia, (tetapi) takutlah kepada-Ku. Dan janganlah kamu menukar ayatayat-Ku dengan harga yang sedikit. Barangsiapa yang tidak memutuskan menurut apa yang diturunkan Allah, maka mereka itu adalah orangorang yang kafir". (QS. Al Maidah [5] : 44)

${ }^{49}$ Rosihon Anwar. 2009. Pengantar Ulumul Qur'an. Bandung: Pustaka setia. hlm. 196., dalam Raden Luhur, "Penyimpangan AlQur'an,".
} 
dan praktis ('amali). ${ }^{50}$ Sekilas, ketiga corak ini terlihat tidak memiliki peluang untuk terjadiknya penyimpangan dalam tafsir sufi. Akan tetapi, peluang terjadinya penyimpangan tersebut akan terbuka lebar ketika para sufi terlalu "memaksakan" ayat-ayat Al-Qur'an untuk diseleraskan dengan doktrindoktrin tasawuf. ${ }^{51}$ Seperti penggunaan tafsir sufi 'amali yang menafsirkan AlQur'an dengan cara mentakwilkan ayatayat Al-Qur'an dengan berdasarkan isyarat-isyarat yang tersembunyi yang hanya diketahui oleh seorang sufi tatkala mereka melakukan suluk. Artinya, eksklusifitas ini memberikan pemahaman bahwa kemungkinan besar hanya para sufi yang mengetahui maksud dari ayat itu. Oleh karenanya, tatkala pengetahuan (tafsir Al-Qur'an) tersebut ia tuangkan dalam sebuah tulisan, maka tidak menutup kemungkinan justru akan membingungkan pembacanya. Bahkan, lebih jauh, lagi dapat menjadikan pemahaman yang menyimpang bagi pembaca tafsir itu.

${ }^{50}$ Tafsir sufi an nadzari ialah sebuah cara yang dilakukan oleh mufassir dalam menafsirkan Al-Qur'an dengan menggunakan madzhabnya, sesuai dengan ajaran mereka. Tafsir sufi isyari adalah sebuah langkah yang dilakukan oleh mufassir dalam menafsirkan AlQur'an dengan menggunakan isyarat-isyarat yang ada pada ayat-ayat yang ditafsirkan. Sedangkan tafsir sufi al 'amali merupakan sebuah cara mufassir untuk menafsirkan AlQur'an dengan cara mentakwilkan ayat-ayat AlQur'an dengan berdasarkan isyarat-isyarat yang tersembunyi yang hanya diketahui oleh seorang sufi tatkala mereka melakukan suluk.

51 Rosihon Anwar. 2009. Pengantar Ulumul Qur'an. Bandung: Pustaka setia, dalam Raden Luhur, "Penyimpangan Al-Qur'an,".
Salah satu dari tafsir sufi adalah sebuah penafsiran yang disampaikan oleh Ibnu Arabi. Seperti Abu Yazid AlBustami dan Al-Hallaj, Ibnu Arabi cenderung menafsirkan ayat-ayat AlQur'an untuk menjustifikasi doktrin "wihdatul wujud" (kesatuan eksistensi). ${ }^{52}$ Hal ini dapat telihat ketika ia mentafsirkan Al-Qur'an surat AlBaqarah ayat 67.

$$
\begin{aligned}
& \text { وَإِذْ قَالَ مُونَسى لِقََوْهِهِ إِنَّ }
\end{aligned}
$$

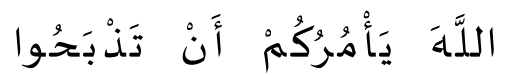

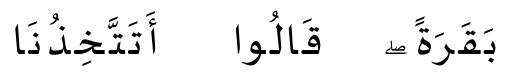

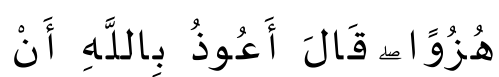

$$
\begin{aligned}
& \text { أَكُونَ مِنَ الْجَاهِلِلِينَ }
\end{aligned}
$$

"Dan (ingatlah), ketika Musa berkata kepada kaumnya: "Sesungguhnya Allah menyuruh kamu menyembelih seekor sapi betina". Mereka berkata: "Apakah kamu hendak menjadikan kami buah ejekan?" Musa menjawab: "Aku berlindung kepada Allah agar tidak menjadi salah seorang dari orangorang yang jahil". (QS. Al Bqarah [2]: 67)

Ibnu Arabi mengatakan bahwa "anak sapi yang disembelih oleh Bani Israil merupakan salah satu manifestasi Allah dan sekaligus dijadikan sebagai

52 Rosihon Anwar. 2009. Pengantar Ulumul Qur'an. Bandung: Pustaka setia, dalam Raden Luhur, "Penyimpangan Al-Qur'an". 
tempat bagi-Nya".53 Penafsiran ayat tersebut tidak mudah dipahami oleh kalangan awam, dan menjadi ranah para sufi. Dampaknya, kalangan awam yang membaca tafsir tersebut dapat berakibat pada pemahaman yang menyimpang. Oleh karenanya, tafsir sufi harus memenuhi beberapa syarat agar dapat diterima, sebagaimana yang dikemukakan oleh 'Abd Al-Hayy AlFarmawi. Syarat-syarat tersebut adalah; a) tidak bertentangan dengan zahir ayat, b) penafsiran diperkuat oleh dalil syara' lain, c) penafsiran tidak bertentangan dengan syari'at dan akal sehat, dan d) mufassir tidak menganggap bahwa penafsirannya adalah satu-satunya tafsir yang benar. ${ }^{54}$

\section{Penyimpangan dalam Tafsir Linguistik (bi lughah) ${ }^{55}$}

Al-Qur'an adalah sebuah kitab suci yang sangat sarat akan makna, dan belum diketahui hakikat makna yang terkandung di dalamnya tanpa pengetahuan yang mendalam tentang ilmu bahasa Arab. ${ }^{56}$ Ini berarti bahwa penguasaan Bahasa Arab dalam memahami Al-Qur'an mutlak diperlukan guna menafsirkan AlQur'an. Seseorang yang tidak memiliki

53 Rosihon Anwar. 2009. Pengantar Ulumul Qur'an. Bandung: Pustaka setia, hlm. 196, dalam Raden Luhur, "Penyimpangan AlQur'an,".

54 'Abd al-Hayy Al-Farmawwi. 1977. al Bidayah $f i$ al Tafsir al Maudhu'i. Mesir: Mathba'at al Hidharat al-'Arabiyah, hlm. 31.

${ }^{55}$ Rosihon Anwar. 2009. Pengantar Ulumul Qur'an. Bandung: Pustaka setia, 196 dalam Raden Luhur, "Penyimpangan AlQur'an".

${ }^{56}$ Ali Hasan Al-‘Arid. 1994. Sejarah dan Metodologi Tafsir. Jakarta: Raja Grafindo Persada, cet. II, hlm. 4. pemahaman terhadap Bahasa Arab akan melahirkan sebuah tafsir yang menyimpang dari makna yang sesungguhnya dimaksud dalam AlQur'an. Sebab, Bahasa Arab memegang peranan penting, sehingga seorang mufassir dapat memahami tentang pola pembentukan kata dan penghubung antar kata dan kalimat guna menafsirkan Al-Qur'an.

Chirzin menyebut bila seorang berbicara dan menulis tafsir Al-Qur'an tanpa memiliki pengetahuan yang memadai tentang kaidah dan aturan Bahasa Arab, ia cenderung akan melakukan kesalahan dan penyimpangan dalam menafsirkan AlQur'an dan memberikan arti etimologis suatu lafal Al-Qur'an dengan arti yang lain yang tidak sesuai, baik dalam arti hakiki maupun dalam arti kiasan. ${ }^{57}$ Penyimpangan tersebut akan lebih terlihat dalam tafsir linguistik yang mengedepankan aspek pemahaman terhadap bahasa, sehingga ketidakfahaman terhadap konjungsi (tashrif) dalam Bahasa Arab akan berakibat fatal bagi penafsiran AlQur'an. Zamaksyari memberikan contoh terkait hal ini dengan mengutip QS. Al Isra' [17]: 71:

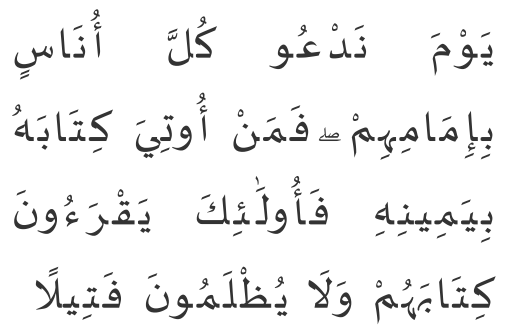

57 Muhammad Chirzin. 2003. Permata Al-Quran. Yogyakarta: Qirtas. hlm. 85. 
"(Ingatlah) suatu hari (yang di hari itu) Kami panggil tiap umat dengan pemimpinnya; dan barangsiapa yang diberikan kitab amalannya di tangan kanannya maka mereka ini akan membaca kitabnya itu, dan mereka tidak dianiaya sedikitpun".

Menurut Az Zamaksyari merupakan penyimpangan penafsiran yang paling besar ketika kata "imam" dianggap sebagai pembentuk dari kata "umn" yang berarti "ibu". Padahal yang benar, bentuk jamak dari kata "umn" itu bukan "imam" melainkan "ummahat."58 Meski pada satu sumber Az Zamaksyari diungkapkan berkata demikian, pada sumber yang lain yang dikutip oleh Adz Dzahabi disebutkan bahwa memang benar kata imam pada ayat tersebut dipahami sebagai bentuk jamak dari kata umum yang berarti ibu. Ini bermakna pada hari kiamat orang akan dipanggil disertai dengan nama ibu. Pemanggilan dengan nama ibu, bukan nama ayah ini untuk menjaga perasaan nabi Isa. ${ }^{59}$

5. Penyimpangan dalam Tafsir Ilmi ${ }^{60}$

Klaim penulis Tafsir Ilmi bahwa Al-Qur'an mencakup segala sesuatu, tidak dapat disalahkan. Setidak-tidaknya klaim mereka didukung oleh Al-Qur'an

58 Rosihon Anwar. 2009. Pengantar Ulumul Quran. Bandung: Pustaka setia. hlm. 196, dalam Raden Luhur, "Penyimpangan AlQur'an,".

59 Muhammad Chirzin. Permata AlQur.an. hlm. 86.

${ }^{60}$ Rosihon Anwar. 2009. Pengantar Ulumul Quran. Bandung: Pustaka setia. hlm. 196. dalam Raden Luhur, "Penyimpangan AlQur'an".
Surat Al-An'am Ayat 38. ${ }^{61}$ Akan tetapi, mereka keliru ketika memperlakukan Al-Qur'an pada buku ilmu pengetahuan, sehingga setiap penemuan ilmu pengetahuan mereka cocok-cocokkan dengan istilah-istilah Al-Qur'an, kendatipun harus melakukan penyimpangan-penyimpangan makna. Betul, Surat Al-An'am Ayat 38 menyatakan bahwa tak sesuatu pun juga Allah tinggalkan dalam Al-Qur'an, tetapi yang dimaksud oleh ayat itu, adalah bahwa Al-Qur'an berisi prinsipprinsip umum mengenai segala sesuatu. Dan mengenai perinciannya, manusia diberi otoritas untuk mengembangkankannya.

Thanthawi Jauhari adalah seorang ulama modern yang sangat fanatik terhadap corak tafsir ilmi. Dalam karyanya, Tafsir Al-Jawahir fi Tafsir AlQur'an, ia menjelaskan ayat-ayat AlQur'an yang diduganya berkaitan dengan ilmu pengetahuan dengan teoriteori ilmu pengetahuan yang "in" pada masanya. Karya tafsirnya itu memeng lebih layak dikatakan sebagai buku ilmu pengetahuan ketimbang sebagai buku

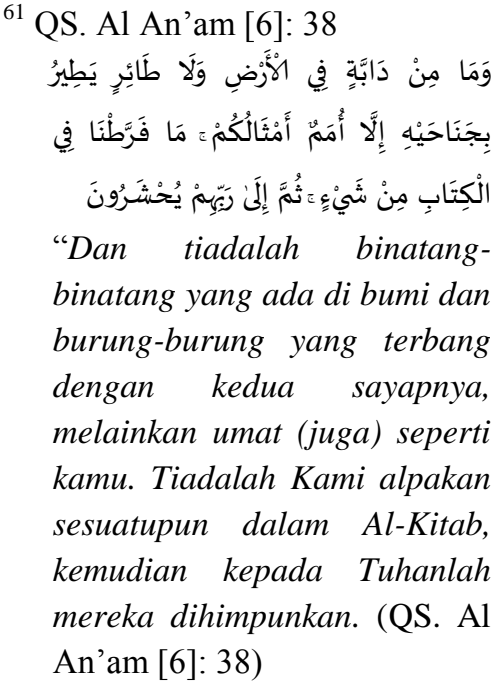


tafsir, sehingga ada ungkapan 'di dalamnya terdapat sesuatu, kecuali tafsir itu sendiri."

\section{Penyimpangan dalam Tafsir Modern}

Modernisasi dalam Islam merupakan satu keharusan bila islam tidak ingin dikatakan sebagai agama yang out of date. Akan tetapi modernisasi itu harus dilakukan dengan prosedur yang tepat dan proporsional. Ketika Al-Qur'an hanya dijadikan justifikasi bagi isu-isu modern yang nota bene muncul dari luar islam, di sana terdapat penyimpanganpenyimpangan dalam tafsir modernisasi. Umpamanya, para para pembaharu "terpaksa meniadakan kewajiban hukum potong tangan bagi tindakan kriminal pencurian yang jelas-jelas ada ketentuannya dalam Al-Qur'an.

\section{Kekurangan dalam Tafsir Tahlili}

Secara umum kekurangan pada tafsir tahlili di antaranya adalah; a) Menjadikan petunjuk Al-Qur'an terlihat parsial (terpisah-pisah), sehingga terkesan Al-Qur'an sebagai kitab suci yang memberikan pedoman hidup tidak secara utuh dan tidak konsisten sebab penafsiran yang diberikan pada suatu ayat berbeda dengan ayat-ayat yang lain yang sama dengannya. Ketidakmauan para mufassir untuk memerhatikan ayatayat yang lain disebut sebagai sebuah konsekuensi logis dari penggunaan metode penafsiran analitis, sebab pada metode ini tidak ada keharusan bagi mufassir untuk membandingkan penafsiran suatu ayat dengan ayat yang lain, seperti yang diutamakan dalam tafsir dengan metode yang lain, semisal metode komparatif. b) Penggunaan metode tahlili dalam tafsir Al-Qur'an juga membuka peluang adanya subjektifitas dalam penafsiran, sehingga bersifat subjektif. Hal ini disebabkan karena analisis yang dilakukan oleh para mufassir tidak akan pernah bisa terlepas dari latar belakang dan subjektifitas mufassir itu sendiri. c) Tidak mampu memberikan jawaban tuntas terhadap persoalan-persoalan yang dihadapi. d) Sama seperti beberapa tafsir yang lain seperti tafsir tabiin, penafsiran Al-Qur'an dengan menggunakan metode tahlili juga terbuka bagi masuknya pemikiranpemikiran israili ayat. ${ }^{62}$

\section{G. Penutup}

Tafsir merupakan cara untuk memahami Al-Qur'an. Keberadaannya menjadi sebuah keharusan karena ayatayat yang terdapat dalam Al-Qur'an bersifat umum, sehingga tidak mudah untuk dipahami. Pemahaman ayat-ayat Al-Qur'an dilakukan dengan menggunakan metode-metode tafsir yang ada, seperti bi al ma'tsur, bi ar ra'yi, dan bi isyari. Ketiga metode ini akan mendekatkan seseorang kepada makna yang sebenarnya terkandung dalam Al-Qur'an. Akan tetapi, perjalanan menuju makna yang sesungguhnya terdapat dalam AlQur'an tidaklah mudah. Terdapat berbagai hal yang menyebabkan seseorang terlalu jauh dari pemahaman terhadap makna Al-Qur'an yang sesungguhnya. Berbagai faktor dan

${ }^{62}$ Nashrudin Baidan. 2008. Metodologi Penafsiran Al-Qur'an. Yogyakarta: Glaguh UHIV, hlm. 59-60. 
bentuk penyimpangan yang ada dalam tafsir pun membawa seseorang dalam pemahaman yang jauh.

Lahirnya penyimpangan dalam tafsir dapat dilihat dari setidaknya empat faktor. Faktor kesamaran karena jarak antara nabi dengan umat yang cukup jauh, faktor internal mufassir sendiri, faktor materi, dan faktor historis. Ketiganya berkontribusi dan menjadi penyebab yang serius yang mengakibatkan peyimpangan terhadap tafsir. Faktor tersebut tidak dapat dihindari dengan mudah, akan tetapi dapat diminimalisir, agar pemahaman terhadap Al-Qur'an tidak semakin jauh dari makna yang diharapkan. Bila faktor-faktor penyebab penyimpangan dalam penafsiran Al-Qur'an tidak diminimalisir, maka akan berakibat pemahaman yang menyimpang dari makna sesungguhnya yang ada dalam Al-Qur'an. Oleh sebab itu, penafsiran Al-Qur'an bukanlah sesuatu yang mutlak, sehingga terbuka untuk dikoreksi dan ditafsirkan kembali.

\section{DAFTAR PUSTAKA}

'Aridl, Ali Hasan. 1994. Sejarah dan Metodologi Tafsir. Jakarta: Raja Grafindo Persada, cet. II.

Adz Dzhahabi, Muhammad Husein. 1976. al-Tafsir wa al-Mufassirun Vol I. Beirut: Dar Ilya al-Turath al-Arabi.

1976. at Tafsir wa al Mufassirun.

Cairo: Dar al Kutub al-Arabi, 1976. Jilid II.

Al Munawar, Said Agil Husin. 2005. Al-Qur'an Membangun Tradisi Kesalehan Hakiki. Tagerang Selatan: Ciputat.
Al Qaththan, Manna' Khalil. Studi Ilmu-ilmu Al-Qur'an. Bogor: Litera Antar Nusa, t.t. cet. II. 1992. Munahis fi Ulum AlQur'an. Riyadh: al Maktabah al Ma'arif lan an Nasyri qa at Tanzil. Al Farmawwi, 'Abd al-Hayy. 1977. al Bidayah fi al Tafsir al Maudhu'i. Mesir: Mathba'at al Hidharat al'Arabiyah.

Al-Zafzaf, Muhammad. al-Ta'rifbi alQur'an wa al-Hadith. Kairo: Kulliyat Dar al-Ulum Jami' alQohirah, t.t.

Amri, Arie Muchlina. "Metode Penafsiran Al-Qur'an," Jurnal Insyiah Vol. 2 No. 1.

Anshori, Aik Iksan. 2012. Tafsir Ishari Pendekatan Hermeneutika Sufistik Tafsir Shaikh 'Abd al Qadir al Jilani. Jakarta: Referensi.

Arifin, 2008. Sejarah Tafsir Klasik dan Kontemporer. Surakarta: STAIN Surakarta.

Ash Shiddieqy, Muhammad Hasbi. 1965. Sejarah dan Pengantar Ilmu Al-Qur'an dan Tafsir. TKT: Bulan Bintang.

Ash Shiddiqy, Hasbi. 1999. Sejarah dan Pengantar Ilmu Hadis. Semarang: Pustaka Rizki Putra, Cet. V.

1997. Sejarah dan Pengantar Ilmu Al-Qur'an dan Tafsir. Semarang: PT. Pustaka Rizky Putra.

Azra (ed), Azyumardi. Sejarah dan Ulum al-Qur'an. Jakarta: Pustaka Firdaus, t.t.

Baidan, Nashrudin. 2008. Metodologi Penafsiran Al-Qur'an. Yogyakarta: Glaguh UHIV. 
Chirzin, Muhammad. 2003. Permata Al-Qur'an. Yogyakarta: Qirtas.

Ismail, Ahmad Satori. 2012. Islam Moderat: Menebar Islam Rahmatan Lil 'Alamin. Jakarta: Pustaka IKADI.

Izzan, Ahmad. 2011. Metodologi Ilmu Tafsir. Bandung: Tafakur.

Macais, Charles Diehl dan Georges. 1936. Le Monde Orientalde. Paris: Histoire Generale.

Manzhur, Ibnu. Lisan Al Arab. Beirut: Daar Shadir, t.t.

Masyhur, Kahyar. 1992. Pokok-pokok Ulumul Qur'an. Jakarta: Rineka Cipta.

Muchlas, Imam. 1995. Al-Qur'an Berbicara: Kajian Kontekstual Beragam Persoalan. Sidoarjo: Pustaka Progresif.

Qardhawi, Yusuf. 1997. Al-Qur'an dan As Sunnah: Referensi Tertinggi Umat Islam, terj. Jakarta: Rabbani Pers.

Raya, Ahmad Thib. 2013. "Kaidah Tafsir Terkait dengan Metode Tafsir: Terjemahan dari Buku Qawa'id al-Tafsir Jam'an wa Dirasat Oleh Khalid al-Sabt.
Tangerang Selatan: Yayasan Lentera Hati.

Shihab, Muhammad Quraisy. 1989. "Ibnu Jarir al-Tabariy," Ulumul Qur'an No. 1,

2013. Kaidah Tafsir, Syarat, Ketentuan, dan Aturan yang Patut Anda Ketahui dalam Memahami Ayat-Ayat Al-Qur'an. Tangerang Selatan: Lentera Hati, 2012. Membumikan Al-Qur'an: Fungsi dan Peran Wahyu dalam Kehidupan Masyarakat. Bandung: Mizan.

1997. Membumikan Al-Qur'an: Fungsi dan Peran Wahyu dalam Kehidupan Masyarakat. Bandung: Mizan.

2002. Tafsir Al Misbah: Pesan, Kesan dan Keserasian Al-Qur'an. Jakarta: Lentera Hati, Vol. 2.

Supiana dan M. Karman. 2012. 'Ulumul Qur'an dan Pengenalan Metodologi Tafsir. Bandung: Pustaka Islamika.

Tasbih, 2013. "Kedudukan dan Fungsi Kaidah-Kaidah Tafsir," Jurnal Farabi Vol. 10, no. 1 Juni. 


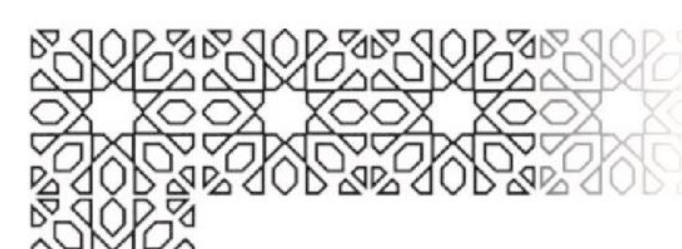

D, 100



of 